\section{Assessing Comparability of ACCounting Information Using Pane Data Analysis}

Lecturer loan-Bogdan ROBU, Ph. D., Faculty of Economics and Business Administration, "Alexandru Ioan Cuza" University of lasi, e-mail: bogdan.robu@feaa.uaic.ro

Lecturer lonut Viorel HERGHILIGIU, Ph. D., "Gheorghe Asachi" Technical University of laşi, e-mail: herghiligiuionut@gmail.com

Bogdan BUDEANU, Ph. D.,

"Gheorghe Asachi" Technical University of laşi, e-mail: bogdan.budeanu@tuiasi.ro

Sorin CHIRU, Ph. D., Internal Auditor, Clinical Recovery Hospital of lasi, e-mail: sorichiru@yahoo.com

\section{Alustract}

Information comparability can be ensured by consistently applying the same financial reporting framework or similar financial reporting frameworks. The comparability of financial information can be measured both between firms and from one period to another. In the study there has been evaluated the comparability of accounting information over time, from one financial exercise to another, and in space, between firms, with panel data analysis using models with fixed-effects. The study was conducted on a sample of 63 BSE Romanian listed companies, during the period 2007-2016, and to obtain the research results, panel data analysis was performed. The main results have revealed that the move to IFRS has led to increased comparability of financial information, based on the estimates of time and cross fixed effects.

Keywords: accounting information, accounting quality, comparability, IFRS, panel data analysis

JEL Classification: C13, C20, C58, M41

To cite this article:

Robu. I-B., Herghiligiu, I. V., Budeanu, B., Chiru, S. (2019), Assessing Comparability of Accounting Information Using Panel Data Analysis, Audit Financiar, vol. XVII, no. 3(155)/2019, pp.441-451,

DOI: 10.20869/AUDITF/2019/155/015

To link this article:

http://dx.doi.org/10.20869/AUDITF/2019/155/015

Received: 16.04.2019

Revised: 30.04.2019

Accepted: 10.05.2019 


\section{Introduction}

The IASB's general framework specifies that accounting information reported by a firm is useful when it can be compared to information reported by other similar firms or information reported by the same firm but in different time periods (IASB, 2015, p. A34). The comparability of accounting information can be ensured by consistently applying the same financial reporting framework or similar financial reporting frameworks and its measurement can be achieved through comparability indexes (Gray et al., 2009, pp. 431-447).

The comparability of the reported accounting information is influenced by the financial reporting system to which a firm subscribes, influenced in turn by a number of cultural, social or economic factors (Nobes and Sandler, 2013, pp. 573-595). The impact of these factors on the comparability of accounting information can be found at the level of reporting, content, and even at the level of the values recorded for certain financial indicators. Differences in financial reporting due to membership of a particular accounting system may lead to different performance records, although the companies under review record comparable values (total assets), number of employees and turnover (Rossetti and Verona, 2017, p. 30).

The adoption of IFRS is a desideratum in reflecting a true and a fair view on the financial position and performance. Comparability may highlight convergence to IFRS or significant differences between this reporting referential (IFRS) and local or national standards. According to IFRS, comparability helps users of accounting information to identify differences or similarities between a set of items included in the financial statements (IASB, 2015, A34).

The purpose of this study is to assess the quality of accounting information, in terms of comparability, at the level of the Romanian companies listed on the Bucharest Stock Exchange (BSE), under the transition to the new financial reporting system - IFRS, proposed by the IASB. In the study, the comparability assessment is performed by using panel data analysis (Jaba et al., 2017, p. 5).

The paper is structured as follows: a section on literature review and hypothesis development, a section dedicated to research methodology, a section on results and discussion, and finally the section dedicated to the research conclusions.

\section{Literature review and

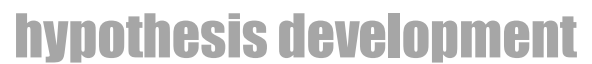

Accounting information provides a relevant description and in the most significant aspects of the financial system, and it must provide to all users a good presentation of the financial position and performance that a firm record in a financial year. The true and the fair view of financial position and performance is ensured by reporting and presenting standardized financial statements (IAS 1, IASB, 2015, p. A738).

Using accounting information, existing and potential investors, creditors and equity lenders can estimate the value of the firm (IASB, 2015, A32). Also, based on reported information, users can identify firm strengths and vulnerabilities, assess their liquidity and solvency, the need for additional funding, probability of obtaining funding, and last but not least prospects for future cash flows (Vernimmen et al., 2009, p. 17).

In order that accounting information to be useful, the IASB's conceptual general reporting framework (issued on January 1,2015$)$ proposes a set of quality characteristics, structured in two groups, the fundamental characteristics and the ones that amplify the first ones (IASB, 2015, pp. A31-A35). In the category of the fundamental quality characteristics are included the value relevance and the faithful representation, and in the category of the quality characteristics that amplifies the first ones, are included: comparability, verifiability, timeliness and understandability (IASB, 2015, pp. A31-A35; Istrate, 2016.b, p. 30).

The accounting quality can be assessed by using quality criteria (Isaic-Maniu and Voda, 1998; Jemna, 2005). Based on quality criteria and indicators, end-users of the information transmitted can make judgments and make decisions (Wang et al., 1995, p. 350; Wand and Wang, 1996, p. 87). The quality of accounting information is intended to give the financial position and financial performance of the firm as much is possible, without being materially misstated by fraud or errors (Robu et al., 2016, pp. 602-603).

Ensuring the quality of accounting information can be achieved on the basis of recognized and accepted international reporting references (Hansen, 1991, p. 30; Barth et al., 2008, p. 468), such as IASB (The International Accounting Standards Board) or the FASB (The Financial Accounting Standards Board) in order to 
minimize the determining factors that lead to the occurrence of frauds and errors and to increase transparency in financial reporting (Barth et al., 2012, pp. 69-70).

The comparability of the accounting information is based on the possibility of identifying certain differences or asymmetries both between messages sent from the same source to different users and from the same source but to one user at different times (Jemna, 2005, p. 46). The issue of comparability is aimed at identifying similarities or differences between accounting information reported by the same firm but at different times (using or not common accounting references) or at the same time, or between information reported by the firm and other firms with which it can be compared, based on the use of a common accounting reference (Christensen and Demsky, 2008, p. 427; Dick and Missonier-Piera, 2010, pp. 20-21).

Comparability can be ensured by applying a common reporting framework, by using the same currency in which the values of items describing position and financial performance are expressed, or by calculating some financial ratios (Barth et al., 2012, pp. 69 -70).

Compliance with IFRS provides users with: a) substantiating the decisions to purchase, store or sell assets; $b$ ) assessing the management and management's accountability capacity; $c$ ) assessing the ability to pay staff, to provide benefits to its employees; d) assessing the guarantees the firm can provide for the credits that have been granted to it; e) compliance with fiscal policies; f) determining profit and dividends to be distributed; g) development and use of statistical data on national income; $h$ ) regulating the business of the company (IASB, 2015, p. A22).

Measuring the difference between IFRS and national rules can be achieved using a comparability index $-\mathrm{Cl}$ (Gray, 1980, pp. 64-76; Gray et al., 2009, pp. 431-447):

$C l=1-($ ValuelFRS - ValueNIFRS)/(|ValueNIFRS|)

where,

$\mathrm{C} /$ represents the comparability index for which values higher than 1 show a decrease in the values of indicators obtained under the IFRS (ValueIFRS) against ValueNIFRS (the values of the indicators obtained under the application of the national financial reporting rules), while a sub-unitary value reflects the opposite - an increase in the figures due to the changeover to IFRSs.
Comparability of accounting information can be assessed both between firms (applying similar accounting rules) and from one period to another (when switching to another reporting framework). Identifying differences between firms but also over time may explain changes in the response of key users to the disclosure of accounting information in financial statements (Barth et al., 2012, pp. 68-93).

Starting from the evidence presented in the literature from the field, the following research hypothesis is proposed in the study to be validated:

$H$ : The transition to IFRS has led to significant differences in the financial reporting of BSE listed companies from one period to another, but has ensured the comparability of financial information between firms.

Starting from this hypothesis, the study proposes the estimation of the differences indicating the existence of the comparability of the accounting information from one financial year to the other, as well as the differences indicating the existence of the comparability of the accounting information from one firm to the other.

\section{Research methodology}

In order to achieve the objectives proposed in the study and to obtain the research, a statistical approach is taken in defining the analysis problems and choosing the models and methods of analysis, observing and collecting the data used in the analysis, processing and statistical analysis of the collected data, and at the last stage the interpretation the results obtained and decision-making (Bărbat, 1972, p. 33; Jaba, 2002, p. 15).

In the study it was analyzed the comparability of accounting information both in time, from one financial exercise to another, and between firms. The comparability assessment was carried out with panel data analysis using fixed-effects models. The estimation of nonsignificant fixed time effects indicates the existence of comparability of accounting information from one financial year to another, while non-significant individual fixed effects indicate the existence of comparability of financial information from one firm to another.

\subsection{Target population and sample}

In the paper, for the statistical assessment of the quality of accounting information, the studied population is represented by Romanian companies listed on a 
regulated capital market and applying IFRS in the reporting of financial statements.

In Romania, the main regulated capital market is represented by the Bucharest Stock Exchange (BSE), under the direct supervision of the Financial Supervisory Authority (FSA). Currently, the BSE includes the following sections: Regulated Market - BSE, AeRo (a regulated market dedicated to companies that do not meet the size or seniority criteria to be listed on the Regulated Market) and ATS-International (Alternative Transaction System trading of international shares).

By the end of 2017, the BSE had 403 listed and active companies, as follows: in the Regulated Market section BSE, 87 companies; at the AeRo section, 301 firms; at the ATS-International section, 15 companies.

In the paper, there were selected only the companies included in the first section of BSE, those that are traded on the Regulated Market. Criteria for admission and maintenance on the Regulated Market are much more rigorous for companies included in this section than those listed on AeRo and ATS-International. The main criteria refer to the anticipated market capitalization of at least 1 million euros and at least 3 years of financial reporting. The main post-admission conditions also include the obligation to report to FSA and BSE, the mandatory publication of both annual and quarterly financial statements (subject to statutory audit), and the application of a Corporate Governance Code by firms. These conditions aim at ensuring transparency in financial reporting and obtaining quality of accounting information.

The BSE Regulated Market section comprises two major categories of companies, Premium and Standard. The inclusion of companies listed in one of the two categories is intended to meet a range of minimum capital, minimum performance, financial performance and liquidity criteria (Filip and Raffournier, 2010, p. 83).

By the end of 2017, the BSE Regulated Market section had 87 companies, out of which 24 were Premium companies, 60 were Standard companies, and 3 International (Int')). Only firms included in the Premium and Standard categories, respectively 84 firms were considered in the analysis. Starting from the 84 traded companies in the BSE regulated market (Premium and Standard categories), the following restrictions were taken into account for the selection of the companies included in the final sample: a) the exclusion of companies that have been suspended due to insolvency, bankruptcy or are very rarely traded;

b) the exclusion of companies operating in the banking, investment, insurance or other financial intermediaries, precisely to ensure the comparability of the financial indicators related to the position and the financial performance, provided that such firms are subject to other regulations on financial reporting;

c) the exclusion of companies for which not all the financial and non-financial information necessary for analyzing the analysis was found.

Depending on the restrictions mentioned, the size of the sample analyzed shall be calculated as follows:

Total tradable companies in the BSE Regulated Market section, Premium and Standard categories:

- companies operating in the banking, investment and insurance funds, or acting as financial intermediaries:

- companies for which all the information necessary for the analysis has not been found:

Total sample:

The sample to be analyzed includes 63 Romanian companies listed on the BSE, in Premium and Standard categories, as showed in Table A.1. in the Appendix, for which data were collected during the period 20072016, which ensures a number of 630 observations.

The timely comparability of accounting information has taken into account the two reporting periods under RAS - Romanian reporting standards and IFRS - International Financial Reporting Standards. The reporting period under RAS covers the financial years 2007-2011 and the reporting period under IFRS covers the years 20122016.

\subsection{Variables, data source and methods for data analysis}

Starting from the system of indicators by which the accounting information is reported and valued by the stakeholders, the variables used in the paper refer to the 
main elements that reflect the financial position and performance (Raffournier, 2012, p.16; IASB, 2015, p. A741).

The data for the variables considered in the analysis, from the Table A.1, were collected with the dedicated DataStream Advanced 9.2 software for the 2007-2016 period, thus reducing the collection-record errors.

The assessment of the comparability of accounting information as well as the impact that accounting information may have over time and between firms on investor decisions has been made by using panel data analysis (Jaba et al., 2017, p. 5). The study retains the models with time fixed effects and with fixed individual effects (Figure A.1 from the Appendix).

Starting from the classic model used to assess the value relevance of accounting information based on yields (Barth et al., 2012, pp. 68-93), the following regression model is proposed for analysis:

$$
\begin{aligned}
& \ln (P t / P t-1)=\beta 0+\beta 1 \cdot \Delta R O A+\beta 2 \cdot \Delta R O E+\beta 3 \cdot \Delta F L+ \\
& D F i+D T t+\varepsilon i t
\end{aligned}
$$

where,

$P$ represents the stock price of the company at end of the year,

$\triangle R O A$ represents the relative variation of return on assets,

$\triangle R O E$ represents the relative variation of return on equities,

$\triangle F L$ represents the relative variation of financial leverage,
$D F i$ represents the differences between firms that arise as a result of RAS or IFRS application in the same time period (cross effects),

DTt represents the differences between different time periods for the same firm arising from the application of RAS or IFRS from one financial year to another (time fixed effects).

In the paper, to obtain the results of the research, data analysis was carried out by using IBM SPSS 22.0

(Statistical Package for Social Sciences) and SAS 9.0 (Statistical Analysis Software).

\section{Results and discussions}

Starting from the research objectives proposed in the study, the main reached results consider the identification of the principal components of the Romanian BSE listed companies' financial statements, as well as the estimation of these components' influence on the transparency in financial reporting.

The comparability over the time of accounting information has taken into account the two reporting periods, under RAS - the Romanian Accounting Standards and IFRS - International Financial Reporting Standards. The reporting period under RAS covers the financial years 2007-2011 and the reporting period under IFRS covers the years 2012-2016.

Using ANOVA for the financial ratios included in the equation (2), as well as for the market response to the reporting of the financial statements, namely the price variation, there have been estimated some descriptive statistics, that are summarized in Table no. 1.

\begin{tabular}{|c|c|c|c|c|c|}
\hline \multicolumn{2}{|c|}{ Variables } & $\mathrm{N}$ & Mean & Std. Dev. & Std. Error \\
\hline \multirow[t]{3}{*}{$\ln (\mathrm{Pt} / \mathrm{Pt}-1)$} & 11-IFRS & 314 & .0560 & .57728 & .03258 \\
\hline & 2-RAS & 315 & -.1780 & .80449 & .04533 \\
\hline & \begin{tabular}{|l|} 
Total \\
\end{tabular} & 629 & -.0612 & .70950 & .02829 \\
\hline \multirow[t]{3}{*}{$\mathrm{FL}$} & 1-IFRS & 314 & 490271 & 1.2348750 & .0696880 \\
\hline & 2-RAS & 316 & .770680 & 1.0252554 & .0576751 \\
\hline & Total & 630 & 630921 & 1.1423310 & .0455116 \\
\hline \multirow{3}{*}{ ROA } & 1-IFRS & 314 & .020162 & .0762778 & .0043046 \\
\hline & 2-RAS & 316 & .035472 & .0690888 & .0038865 \\
\hline & \begin{tabular}{|l|} 
Total \\
\end{tabular} & 630 & .027842 & .0731053 & .0029126 \\
\hline \multirow[t]{3}{*}{ ROE } & 1-IFRS & 314 & .048152 & .1401309 & .0079080 \\
\hline & 2-RAS & 316 & .022749 & .1366553 & .0085914 \\
\hline & \begin{tabular}{|l} 
Total \\
\end{tabular} & 630 & .036817 & .1390446 & .0058393 \\
\hline
\end{tabular}

\section{Table no. 1. Descriptive statistics for the variables included in model (2)}

Source: Own processing in SPSS 22.0 
Based on the results presented in Table no. 1, it can be noticed that there are significant differences in the financial position and performance information reported by $B S E$ listed companies under RAS and IFRS. These results lead to the conclusion that there is no comparability between the two reporting referentials. The main differences were recorded at both the level of the indicators related to the profitability and the one related to the financial structure.

The main results obtained under SAS 9.0 refer to a series of statistics related to the proposed model (Table no. 2), testing the model with fixed effects using the $F$ test (Table no. 3), testing the model using the Hausman test (Table no. 4) and the estimations for the fixed effects model (Table A.1 from Appendix).

\section{Table no. 2. Statistics related to the model with cross and fixed effects}

\section{Statistics for the model with fixed effects}

\begin{tabular}{|r|r|r|r|}
\hline SSE & 7226808.644 & DFE & 491 \\
\hline MSE & 14718.5512 & Square root of MSE & 121.3200 \\
\hline $\mathbf{R}^{2}$ & 0.1267 & & \\
\hline
\end{tabular}

SSE = Sum of squares of errors;

$D F E=$ The number of degrees of freedom associated with errors: the number of observations in the data set minus the number of parameters;

MSE = Mean squares of errors.

Source: Own processing in SAS 9.0

From Table no. 2, based on the $R^{2}$ value, it can be seen that $12.67 \%$ from the variance in the variance in the yield of a share (In(Pt/Pt-1)) is explained by the influence of $R O A, R O E$ and $F L$, in the case of the model with cross and time fixed effects.

\section{Table no. 3. Testing the Fixed Effect Model with the F Test}

\section{F statistic for testing the existence of fixed effects}

\begin{tabular}{|c|c|c|c|}
\hline No. DF & Den DF & Value of $F$ test & Pr $>F$ \\
\hline 70 & 491 & 1.02 & 0.4474 \\
\hline
\end{tabular}

Source: Own processing in SAS 9.0

The value of the $F$ test, calculated as a ratio between the total variance estimator (MST) and the error variance estimator, is 1.02. This value indicates the absence of cross and time fixed effects at the level of the proposed model in equation (2), although the determinants, $R O A$ and $R O E$, have a significant influence on the variance of the share's yield (In (Pt / Pt-1)).

\section{Table no. 4. Testing the model with fixed effects using the Hausman test}

\begin{tabular}{|c|c|c|}
\hline \multicolumn{3}{|c|}{ Hausman test for random effects } \\
\hline DF & Value of the test & $\operatorname{Pr}>\mathrm{m}$ \\
\hline 3 & 2.11 & 0.5500 \\
\hline
\end{tabular}

Source: Own processing in SAS 9.0 
Table no. 4 complements Table no. 3 by providing the result obtained by applying the Hausman test $\left(H_{0}\right.$ : the model has random effects; $H_{1}$ : the model has no random effects). The Hausman specification test can also be used to test the consistency of the predictors of the proposed model parameters; in the case of the model with time-fixed effects, the null hypothesis $\left(H_{0}\right)$ specifies that the parameter estimators are consistent but inefficient, and in the case of the alternative hypothesis $\left(H_{1}\right)$ the model parameters estimators are consistent and possibly efficient. Based on the results obtained, it can be appreciated that the estimated parameters for the proposed model has no random effects, and the model parameters are consistent but ineffective.

For the time-fixed effects model, the parameter estimates are presented in Table A.1 of the Appendix. Only the estimates of cross and time fixed effects are retained for the study of comparability. The data shown in the table shows the absence of cross and time fixed effects (except for one company, CS6: Aerostar). This highlights the comparability of reported accounting information between firms. Also, the table shows the existence of only one-time fixed effect (TS: 2011) for the financial year 2011, the last year in which RAS was applied in the financial reporting of BSE listed companies. The adoption to IFRSs, starting in 2012, has led to the maintenance of comparability of financial information from one period to another.

\section{Gonclusions}

Using advanced statistical data analysis methods, the quality of financial information can be assessed, as well as the analysis of the influence of its determinants, at the level of each quality feature. As well, advanced statistical data analysis methods can be used to assess the comparability of accounting information.

The use of panel data analysis can provide solutions to the influence in time of specific factors on the quality of accounting information. Estimating the differences in time and between the companies, at the level of the quality of accounting information, can provide clues of its comparability in terms of adopting new financial reporting frameworks, but also of increasing its relevance or faithful representation. The main results have revealed that the IFRS adoption has led to an increase of comparability of accounting information.

The use of panel data analysis contributes to increasing the accuracy of regression model parameter estimates, improving the analysis of a phenomenon by including individual and time dimensions in the model, simplifying the statistical inference process (using the classical assumptions of the regression analysis is not obligatory) (Hsiao, 2003, p. 1).

The panel data analysis can be restricted by recording data, distorting error measurement, selecting individuals included in the analyzed sample, using time series over short periods, by dependence of factors (Baltagi, 2005, pp. 4-9). Typical sampling problems may affect the construction and collection of panel data. The most common problems are to ensure representativeness, occurrence of nonresponses, inaccurate answers or aberrant values, ensuring a constant frequency in data collection, and a set reference period (Baltagi, 2005, pp. 4-9).

A limit of this study is determined by the population observed and by the relatively small volume of the analyzed sample. Compared to international studies, using samples of thousands or tens thousands of firms, the Romanian financial market is characterized by a small number of firms that can be analyzed. This is due precisely to the insufficient development of the Romanian financial market, marked by a normative framework still undergoing transformation. Also, the Romanian experience regarding the implementation and application of reporting referencing to ensure the quality of financial information - IFRS is recent, compared to international practice and experience.

From the point of view of the analysis, future directions aim at conducting international research, including other firms listed on the main European financial markets or that use the IFRS reporting framework. This will make a significant contribution to increasing the quality and the relevance of results achieved at national and international level.

\section{Acknowledgments}

This work was supported by a National Research Grant of the "Gheorghe Asachi" Technical University of lasi, Romania, project number GnaC2018_119.

\section{REFERENCES}

1. Atwood, T.J., Drake, M., Myers, J., Myers, L. (2011), Do earnings reported under IFRS tell us more about future earnings and cash flows?, Journal of Accounting and Public Policy, 30, pp. 103-121 
2. Baltagi, B. (2005), Econometria Analysis of Panel Data, 3rd edition, John Wiley \& Sons, West Sussex, England

3. Barth, M.E., Landsman, W.R., Lang, M.H. (2008), International accounting standards and accounting quality, Journal of Accounting Research, 46(3), pp. 467-498

4. Barth, M.E., Landsman, W., Lang, M., Williams, C. (2012), Are IFRS-based and US GAAP-based accounting amounts comparable?, Journal of Accounting and Economics, 54, pp. 68-93

5. Bărbat, A. (1973), Teoria statisticii sociale, Editura Didactică şi Pedagogică, Bucureşti

6. Christensen, J., Demski, J. (2008), Accounting Theory: An Information Content Perspective, McGraw-Hill Primis

7. Dick, F., Missonier-Piera, F. (2010), Financial reporting under IFRS: a topic-based approach, John Wiley \& Sons, West Sussex

8. Field, A. (2009), Discovering Statistics using SPSS, 3rd edition, SAGE Publication, London

9. Filip, A., Raffournier, B. (2010), The value relevance of earnings in a transition economy: The case of Romania, The International Journal of Accounting, 45(1), pp. 77-103

10. Gray, S.J. (1980), The impact of international accounting differences from a security-analysis perspective: some European evidence, Journal of Accounting Research, 18(1), pp. 64-76

11. Gray, S.J., Linthicum, C. L., Street, D.L. (2009), Have European and US GAAP measures of income and equity converged under IFRS? Evidence from European companies listed in the US, Accounting and Business Research, 39(5), pp. 431-447

12. Hansen, M.D. (1991), Zero defect data. Tacking the corporate data quality problem, MIT, http://dspace.mit.edu/handle/1721.1/13812, accessed on 21.03.2018

13. Hsiao, C. (1999), Analysis of panel data, Cambridge University Press, Cambridge

14. IASB (2015), International Financial Reporting Standards (IFRS) Official regulations issued from January 1, 2015, CECCAR, Bucharest

15. Isaic-Maniu, A., Vodă, V. (1998), Manualul calității, Ed. Economică, Bucureşti

16. Istrate, C. (2016a), Contabilitatea nu-i doar pentru contabili!, Evrika Publishing, Bucureşti
17. Jaba, E. (2002), Statistica, ed. a 3-a, Ed. Economică, Bucureşti

18. Jaba, E., Robu, I.B., Istrate, C., Balan, C.B., Roman, M. (2016), Statistical Assessment of the Value Relevance of Financial Information Reported by Romanian Listed Companies, Romanian Journal of Economic Forecasting, 19(2), pp. 27-42

19. Jaba, E., Robu, I.B., Balan, C.B. (2017), Panel data analysis applied in financial performance assessment, Revista Română de Statistică, 2, pp. 3-20

20. Jemna, D.V. (2005), Eficiența sondajului statistic, Ed. Sedcom Libris, laşi

21. Lang, M., Stice-Lawrence, L. (2014), Textual Analysis and International Financial Reporting: Large Sample Evidence, available at: https://pdfs.semanticscholar.org/e1f5/a44f88c8cef7e6 d70281b03789e334636a7b.pdf accessed on 23.03.2018

22. Nobes, C.W., Stadler, C. (2013), How arbitrary are international accounting classifications? Lesson from centuries of classifying in many disciplines and experiments with IFRS data, Accounting, Organizations and Society, 38, pp. 573-595

23. Raffournier, B. (2012), Les Normes Comptables Internationales (IFRS), 5ème édition, Economica, Paris

24. Robu, I.B., Carp, M., Popescu, C., Păvăloaia, L., Istrate, C., Georgescu, I.E. (2016), The country risk influence on accounting quality in the case of Romanian listed companies, Transformations in Business and Economics, 15(3c), pp. 597-616

25. Rossetti, S., Verona, R., (2017), International Differences in IFRS Policy Choice and the Persistence of Accounting Classification: The Case of China, International Journal of Business and Management, 12(2), pp. 27-46

26. Vernimmen, P., Quiry, P., Dallocchio, M., Le Fur, Y., Salvi, A. (2009), Corporate finance. Theory and practice, 2nd edition, John Wiley \& Sons, West Sussex

27. Wang, R.Y., Reddy, M. P., Kon, H.B. (1995), Toward quality data: Anattribute-based approach, Decision Support Syst., pp. 349-372

28. Wand, Y., and Wang, R. Y. (1996), Anchoring Data Quality Dimensions in Ontological Foundations, Communications of the ACM (39:11), pp. 86-95 


\section{Table A.1. Parameters estimates for the model with fixed effects}

\section{Parameters estimates}

\begin{tabular}{|c|c|c|c|c|c|c|}
\hline Variable & DF & Estimate & Std. Error & T value & $\operatorname{Pr}>|t|$ & Label \\
\hline CS1 & 1 & -1.00916 & 57.3154 & -0.02 & 0.9860 & Cross Sectional Effect 1 \\
\hline CS2 & 1 & 1.722453 & 57.2719 & 0.03 & 0.9760 & Cross Sectional Effect 2 \\
\hline CS3 & 1 & 1.08143 & 57.2507 & 0.02 & 0.9849 & Cross Sectional Effect 3 \\
\hline$\overline{\operatorname{CS} 4}$ & 1 & 0.445955 & 57.2117 & 0.01 & 0.9938 & Cross Sectional Effect 4 \\
\hline CS5 & 1 & -9.71163 & 57.5608 & -0.17 & 0.8661 & Cross Sectional Effect 5 \\
\hline CS6 & 1 & -323.205 & 57.3112 & -5.64 & $<.0001$ & Cross Sectional Effect 6 \\
\hline CS7 & 1 & 0.327731 & 57.3579 & 0.01 & 0.9954 & Cross Sectional Effect 7 \\
\hline CS8 & 1 & 0.072639 & 57.2630 & 0.00 & 0.9990 & Cross Sectional Effect 8 \\
\hline CS9 & 1 & 0.23852 & 57.2312 & 0.00 & 0.9967 & Cross Sectional Effect 9 \\
\hline CS10 & 1 & -1.00066 & 57.2963 & -0.02 & 0.9861 & Cross Sectional Effect 10 \\
\hline CS11 & 1 & -0.77448 & 57.2293 & -0.01 & 0.9892 & Cross Sectional Effect 11 \\
\hline CS12 & 1 & -0.83643 & 57.2317 & -0.01 & 0.9883 & Cross Sectional Effect 12 \\
\hline CS13 & 1 & -2.13001 & 57.4266 & -0.04 & 0.9704 & Cross Sectional Effect 13 \\
\hline CS14 & 1 & -0.63178 & 57.4122 & -0.01 & 0.9912 & Cross Sectional Effect 14 \\
\hline CS15 & 1 & -3.35168 & 57.3593 & -0.06 & 0.9534 & Cross Sectional Effect 15 \\
\hline CS16 & 1 & 1.193345 & 57.2995 & 0.02 & 0.9834 & Cross Sectional Effect 16 \\
\hline CS17 & 1 & 0.703253 & 57.2763 & 0.01 & 0.9902 & Cross Sectional Effect 17 \\
\hline CS18 & 1 & -1.08276 & 57.3001 & -0.02 & 0.9849 & Cross Sectional Effect 18 \\
\hline CS19 & 1 & -2.33626 & 57.2392 & -0.04 & 0.9675 & Cross Sectional Effect 19 \\
\hline CS20 & 1 & -10.9816 & 57.2785 & -0.19 & 0.8480 & Cross Sectional Effect 20 \\
\hline CS21 & 1 & -5.55073 & 57.3981 & -0.10 & 0.9230 & Cross Sectional Effect 21 \\
\hline CS22 & 1 & -2.77558 & 57.3443 & -0.05 & 0.9614 & Cross Sectional Effect 22 \\
\hline CS23 & 1 & 1.100698 & 57.2652 & 0.02 & 0.9847 & Cross Sectional Effect 23 \\
\hline CS24 & 1 & -6.87207 & 59.0711 & -0.12 & 0.9074 & Cross Sectional Effect 24 \\
\hline CS25 & 1 & -4.63501 & 57.2215 & -0.08 & 0.9355 & Cross Sectional Effect 25 \\
\hline CS26 & 1 & 0.80004 & 57.2772 & 0.01 & 0.9889 & Cross Sectional Effect 26 \\
\hline CS27 & 1 & -1.44561 & 57.5442 & -0.03 & 0.9800 & Cross Sectional Effect 27 \\
\hline CS28 & 1 & 1.283593 & 57.2337 & 0.02 & 0.9821 & Cross Sectional Effect 28 \\
\hline CS29 & 1 & 1.025493 & 57.2508 & 0.02 & 0.9857 & Cross Sectional Effect 29 \\
\hline CS30 & 1 & 0.036051 & 57.2129 & 0.00 & 0.9995 & Cross Sectional Effect 30 \\
\hline CS31 & 1 & -3.71103 & 57.7540 & -0.06 & 0.9488 & Cross Sectional Effect 31 \\
\hline CS32 & 1 & -10.3874 & 57.5004 & -0.18 & 0.8567 & Cross Sectional Effect 32 \\
\hline CS33 & 1 & 0.779668 & 57.2178 & 0.01 & 0.9891 & Cross Sectional Effect 33 \\
\hline CS34 & 1 & 0.284308 & 59.1522 & 0.00 & 0.9962 & Cross Sectional Effect 34 \\
\hline CS35 & 1 & 0.389696 & 57.2700 & 0.01 & 0.9946 & Cross Sectional Effect 35 \\
\hline CS36 & 1 & 1.643145 & 57.3851 & 0.03 & 0.9772 & Cross Sectional Effect 36 \\
\hline
\end{tabular}




\begin{tabular}{|c|c|c|c|c|c|c|}
\hline \multicolumn{7}{|c|}{ Parameters estimates } \\
\hline Variable & DF & Estimate & Std. Error & T value & $\operatorname{Pr}>|t|$ & Label \\
\hline CS37 & 1 & -2.98148 & 57.2388 & -0.05 & 0.9585 & Cross Sectional Effect 37 \\
\hline CS38 & 1 & -0.22618 & 57.2330 & -0.00 & 0.9968 & Cross Sectional Effect 38 \\
\hline CS39 & 1 & -3.2983 & 57.4232 & -0.06 & 0.9542 & Cross Sectional Effect 39 \\
\hline CS40 & 1 & -0.99003 & 57.2381 & -0.02 & 0.9862 & Cross Sectional Effect 40 \\
\hline CS41 & 1 & -0.22487 & 57.1911 & -0.00 & 0.9969 & Cross Sectional Effect 41 \\
\hline CS42 & 1 & 1.060595 & 57.3967 & 0.02 & 0.9853 & Cross Sectional Effect 42 \\
\hline CS43 & 1 & 1.723089 & 57.3626 & 0.03 & 0.9760 & Cross Sectional Effect 43 \\
\hline CS44 & 1 & 1.095906 & 57.2207 & 0.02 & 0.9847 & Cross Sectional Effect 44 \\
\hline CS45 & 1 & -1.32113 & 57.2987 & -0.02 & 0.9816 & Cross Sectional Effect 45 \\
\hline CS46 & 1 & -3.00147 & 57.4560 & -0.05 & 0.9584 & Cross Sectional Effect 46 \\
\hline CS47 & 1 & -3.77064 & 57.3613 & -0.07 & 0.9476 & Cross Sectional Effect 47 \\
\hline CS48 & 1 & -4.42145 & 57.4339 & -0.08 & 0.9387 & Cross Sectional Effect 48 \\
\hline CS49 & 1 & 0.99379 & 57.2015 & 0.02 & 0.9861 & Cross Sectional Effect 49 \\
\hline CS50 & 1 & -1.10891 & 57.2809 & -0.02 & 0.9846 & Cross Sectional Effect 50 \\
\hline CS51 & 1 & -0.90982 & 57.2381 & -0.02 & 0.9873 & Cross Sectional Effect 51 \\
\hline CS52 & 1 & 0.516221 & 57.2539 & 0.01 & 0.9928 & Cross Sectional Effect 52 \\
\hline CS53 & 1 & -3.31482 & 57.7753 & -0.06 & 0.9543 & Cross Sectional Effect 53 \\
\hline CS54 & 1 & 0.242856 & 57.1914 & 0.00 & 0.9966 & Cross Sectional Effect 54 \\
\hline CS55 & 1 & 0.306257 & 57.3848 & 0.01 & 0.9957 & Cross Sectional Effect 55 \\
\hline CS56 & 1 & -0.38408 & 57.2590 & -0.01 & 0.9947 & Cross Sectional Effect 56 \\
\hline CS57 & 1 & 1.335047 & 57.1915 & 0.02 & 0.9814 & Cross Sectional Effect 57 \\
\hline CS58 & 1 & -2.8059 & 57.3048 & -0.05 & 0.9610 & Cross Sectional Effect 58 \\
\hline CS59 & 1 & 2.116559 & 57.2763 & 0.04 & 0.9705 & Cross Sectional Effect 59 \\
\hline CS60 & 1 & 2.646005 & 57.2317 & 0.05 & 0.9631 & Cross Sectional Effect 60 \\
\hline CS61 & 1 & 0.464029 & 57.2969 & 0.01 & 0.9935 & Cross Sectional Effect 61 \\
\hline CS62 & 1 & 1.532114 & 57.3114 & 0.03 & 0.9787 & Cross Sectional Effect 62 \\
\hline TS1_2008 & 1 & -8.90866 & 21.6327 & -0.41 & 0.6807 & Time Series Effect 1 \\
\hline TS2_2009 & 1 & 0.942808 & 21.6286 & 0.04 & 0.9652 & Time Series Effect 2 \\
\hline TS3_2010 & 1 & 0.349965 & 21.7784 & 0.02 & 0.9872 & Time Series Effect 3 \\
\hline TS4_2011 & 1 & -47.9221 & 21.7788 & -2.20 & 0.0282 & Time Series Effect 4 \\
\hline TS5_2012 & 1 & -0.9201 & 21.7776 & -0.04 & 0.9663 & Time Series Effect 5 \\
\hline TS6_2013 & 1 & 2.57315 & 21.6427 & 0.12 & 0.9054 & Time Series Effect 6 \\
\hline TS7_2014 & 1 & -0.4929 & 21.6224 & -0.02 & 0.9818 & Time Series Effect 7 \\
\hline TS8_2015 & 1 & -0.28705 & 21.6946 & -0.01 & 0.9894 & Time Series Effect 8 \\
\hline Intercept & 1 & 5.053593 & 42.9770 & 0.12 & 0.9064 & Intercept \\
\hline$\triangle \mathrm{ROA}$ & 1 & 0.015509 & 0.3511 & 0.04 & 0.9648 & \\
\hline$\triangle \mathrm{ROE}$ & 1 & 0.028289 & 0.2647 & 0.10 & 0.9149 & \\
\hline$\Delta \mathrm{FL}$ & 1 & 1.01997 & 1.3661 & 0.75 & 0.4557 & \\
\hline
\end{tabular}

Dependent variable: $\ln \left(P_{t} / P_{t-1}\right)$

Source: Own processing in SAS 9.0 
Figure A.1. Source code in SAS 9.0 used for the pannel analyse of data in the case of fixed and random effects

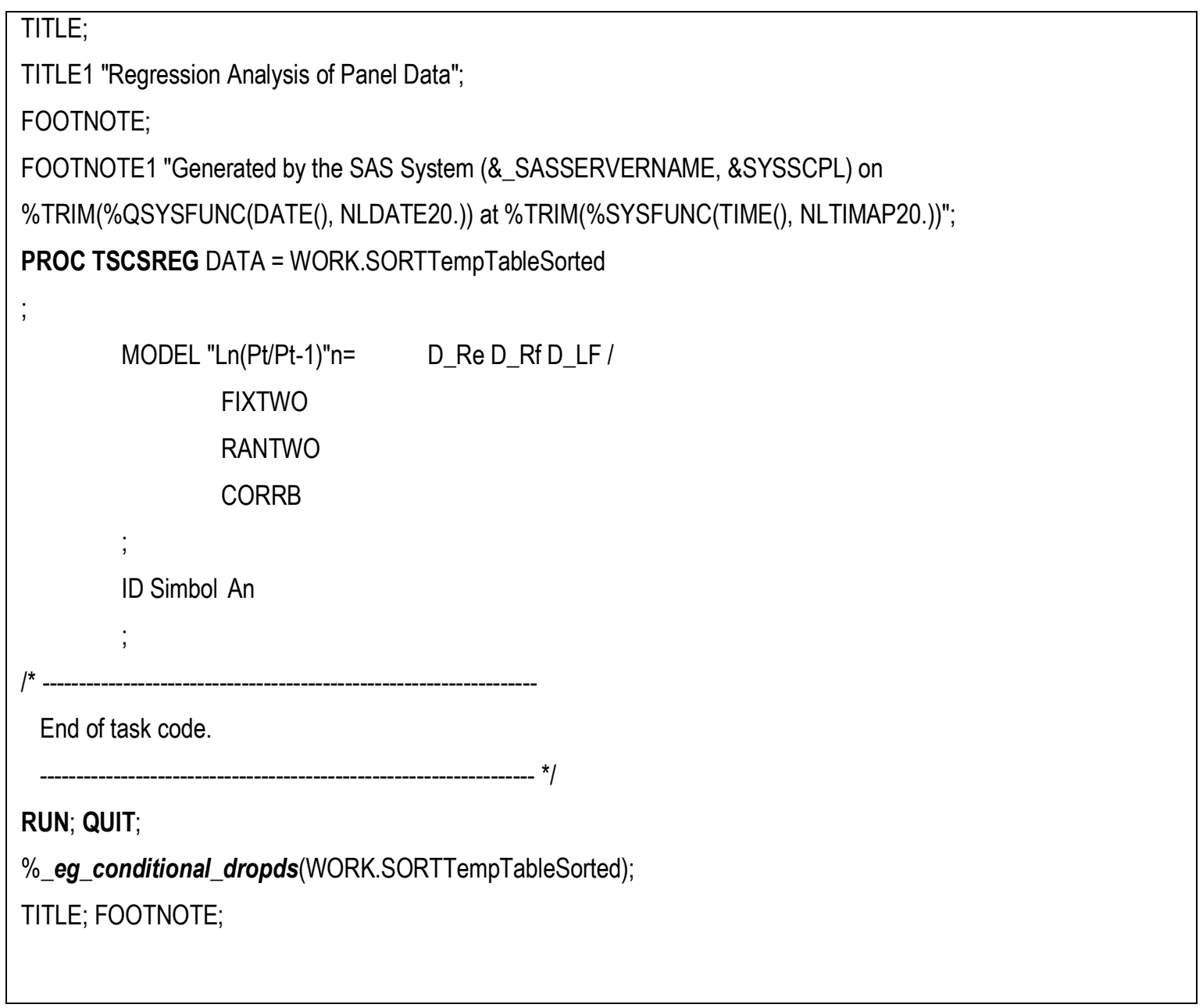

Source: Own processing in SAS 9.0 